\title{
Civic Duty, Moral Responsibility, and Reciprocity
}

An Ethnographic Study on Resident-volunteers in the Neighbourhoods of Beijing

Judith Audin

\section{(2) OpenEdition}

\section{Journals}

Electronic version

URL: http://journals.openedition.org/chinaperspectives/7411

ISSN: 1996-4617

\section{Publisher}

Centre d'étude français sur la Chine contemporaine

\section{Printed version}

Date of publication: 1 September 2017

Number of pages: 47-56

ISSN: 2070-3449

\section{Electronic reference}

Judith Audin, "Civic Duty, Moral Responsibility, and Reciprocity », China Perspectives [Online], 2017/3 |

2017, Online since 01 September 2018, connection on 28 October 2019. URL : http://

journals.openedition.org/chinaperspectives/7411 


\title{
Civic Duty, Moral Responsibility,
}

\section{and Reciprocity}

\author{
An Ethnographic Study on Resident-volunteers in the Neighbourhoods of Beijing
}

\begin{abstract}
This paper, which is based on ethnographic field research, analyses the system of resident-volunteers in the neighbourhoods of Beijing. Between co-optation networks, surveillance missions, ritualised practices, and ordinary exchanges of sociability amongst neighbours, volunteering is an interesting form of citizen participation in urban China. The volunteer networks are made up of inhabitants who are selected and involved through the norms of civic duty, personal acquaintance, moral obligation, or persuasion, in order to contribute to the production of local public order. Finally, this specific form of voluntarism reveals, from the perspective of retired people, how shared socio-political practices are created and perpetuated within an institutional volunteering system.
\end{abstract}

KEYWORDS: Beijing, inhabitants, volunteering, commitment, participation, reciprocity, residents' committee, neighbourhood, ethnography.

\section{Introduction: From "activists" (jijifenzi) to "volunteers" (zhiyuanzhe), the evolution of residents' involvement in the neighbourhoods of Beijing}

\footnotetext{
A $t$ the intersection of two little streets in central Beijing stand two residents wearing red armbands. They are part of the "security brigade" (zhi'an xunluodui):
}

I do this because I have time to spare. I come here once a week for two hours in the morning and two hours in the afternoon. ${ }^{(1)}$

As this scene demonstrates, it is not rare to come across elderly people wearing red armbands, chatting on the pavement, and observing passersby. They are neighbourhood volunteers whose status is ambiguous: "We are activists (iijifenzi) from the residents' committee." But the director of the residents' committee (2) corrects her: "No, you should say something else now, you should say you are volunteers (zhiyuanzhe)." (3)

The term "activist" echoes the policy of inciting the "enthusiastic participation of the masses" implemented from the earliest days of the People's Republic of China. Social control has long involved citizens in the kind of close surveillance found in other authoritarian socialist regimes, notably in Cuba. ${ }^{(4)}$ Large public organisations and institutions such as factories and administrative authorities managed the daily work and lives of workers, employees, and their families through the work unit system. Ideological voluntarism constituted an integral part of the political culture, acting as a system of social control through which workers also obtained protection in the shape of lifelong employment, medical help, and housing (Solomon 1969; Whyte and Parish 1984; Walder 1986; Mok 1988; Shaw 1996). Economic reforms have modified the employment market and limited the predominance of work units, reconfiguring the field of social assistance and care of urban dwellers and focusing on the idea of "neighbourhood communities" (shequ). (5)

Since the 1980s, urban security surveillance has included new players who assist the police. Security guards (bao'an) constitute a new professional category. The job of chengguan appeared in the 1990s with a view to cracking down on illicit commercial practices (Caron 2013). The residents' committees, formerly made up of resident "activists," became more professional, whilst at the same time retaining their ambiguous status as "autonomous local grassroots organisations" (jiceng qunzhongxing zizhi zuzhi).(6) Their officials are now salaried and do not necessarily live in the "neighbourhood community" (shequ) they manage. Their work is now directed towards administrative work and social care. As grassroots organisations, they also claim to be guarantors of the development of "local democracy" (jiceng minzhu) in that they organise elections every three years.

As for the housing that has appeared since the liberalisation of housing policies, this is run by property management companies (wuye guanli

This paper is based on data collected thanks to a post-doctoral contract at EHESS in 2014-2015. The author would like to thank Julien Girault, Jean-Louis Rocca, and Isabelle Thireau, as well as the anonymous reviewers for their advice on previous versions of this article.

1. Red-armband volunteers, historic quarter, 9 April 2007.

2. Residents' committees are organisations designed to manage the population in the neighbourhoods of Chinese cities.

3. Red-armband volunteer and the director of her residents' committee in the historic quarter, 29 September 2007.

4. In Cuba, the "Committees for the Defence of the Revolution," which were rooted into the social fabric of the living environment, have retained a social usefulness (Colomer 2000; Giraldou 2016). In the case of East Germany, the inhabitants were also involved in the management of neighbourhoods, dealing with problems in apartment buildings, against the background of a housing crisis (Rowell 2006).

5. In the post-danwei era, the Ministry of Civil Affairs (minzhengbu) has taken charge of social care once again and in 2000 launched a policy of "neighbourhood community building" (shequ jianshe). These are administrative zones for local management defined according to geographic and demographic variables (Bray 2005)

6. Organic Law of the Urban Residents' Committees of the People's Republic of China, 1989. 


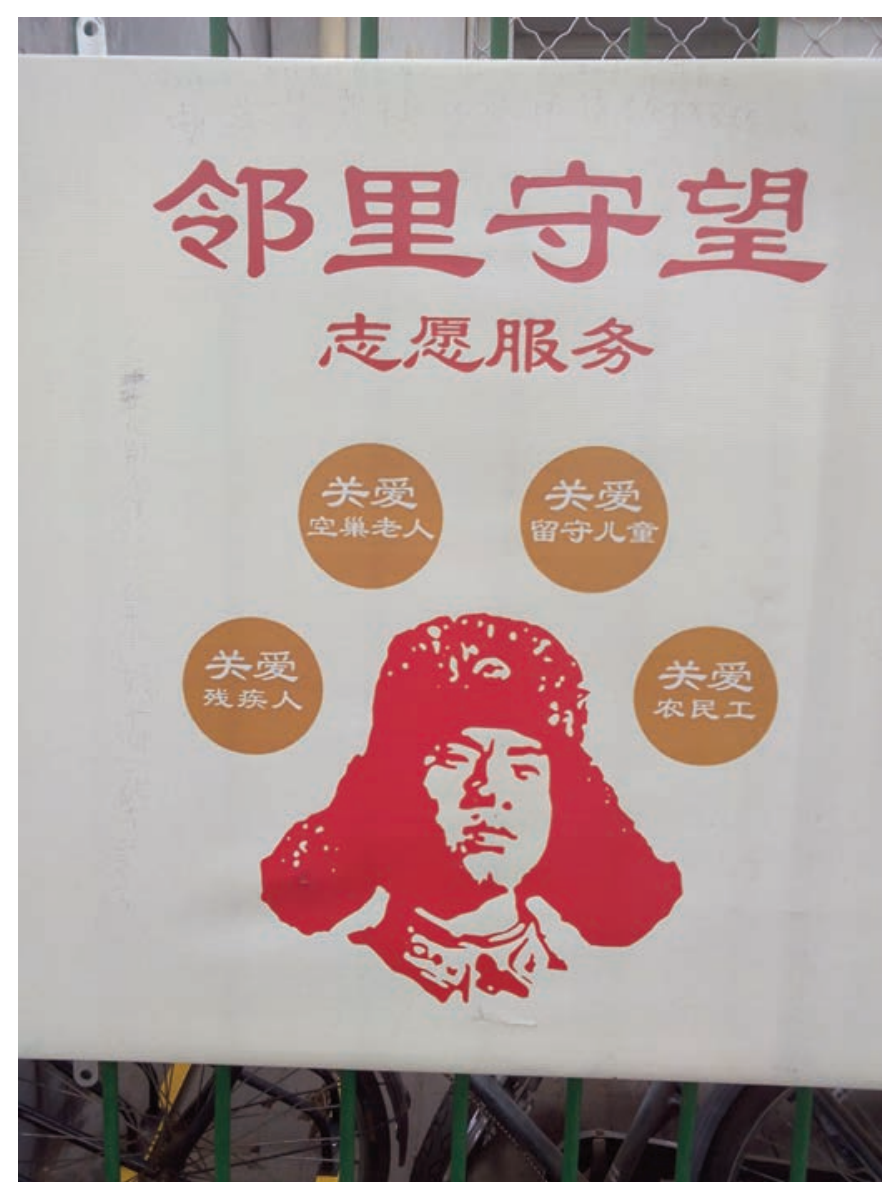

Photo 1 - Surveillance by the neighbours (邻里守望), volunteer services, taking care of the handicapped (关爱残疾人), taking care of lonely elderly people (关爱空巢老人), childminding (关爱留守儿童), looking after migrant workers(关爱 农民工). Poster. @ Judith Audin, April 2015.

gongsi) financed by service charges paid by property owners, who can themselves form committees (yezhu weiyuanhui). Yet even in the context of the professionalization of security and the growing complexity of neighbourhood management, the legacy of neighbourhood surveillance still persists.

In the press, ordinary citizens, known as the "masses," are often quoted by the police as having contributed to the arrest of wrongdoers. The antiterrorist law passed in early 2016 underlined the importance of the role of ordinary people in spotting suspicious activities and in denunciation, encouraging people to inform the police in exchange for payment. (7) However, the official resident-volunteer system (zhiyuanzhe) does not include financial remuneration.

Since the 2000s, charging ordinary citizens with surveillance responsibilities and volunteer services has been reconfigured and is now presented as being inspired by "the West" (xifang). ${ }^{\left({ }^{8}\right)}$ Several years before the 2008 Olympic Games, the municipality of Beijing launched a campaign to recruit 100,000 volunteers, encouraging young people, schoolchildren, and students to become involved on a voluntary basis in tasks such as translation and directing tourists with a view to creating a "civilised" city (wenming). The municipal authorities saluted the success of this policy. (9) Volunteering by young students has already been examined as a ritual of socio-political promotion (Doyon 2016), but the way in which the neighbourhood volunteer networks are formed remains to be developed.
Resident-volunteering has also been the object of campaigns on the part of the public authorities at key political moments. During the hosting of the Olympic Games in Beijing, the system was adapted to fit a Western lexical field ("community building" shequ jianshe, "volunteer" zhiyuanzhe replacing "activist" jijifenzi, and becoming as commonly used as the older idea of yigong) whilst at the same time retaining the vocabulary of the Maoist era, as can be seen in Photo 1, where a list of the principles of volunteering translated from English appears alongside an illustration of the national hero Lei Feng. ${ }^{(10)}$ The Ministry of Civil Affairs, for example, launched a policy of promoting urban volunteer services (zhiyuan fuwu) in 2014. At the end of the year, the media reported that the town of Beijing had more than 1.5 million registered neighbourhood volunteers (shequ zhiyuanzhe), divided into 12,908 teams, and who had performed 19,610,000 hours of service over the year. ${ }^{(11)}$

During the National Congress of the Chinese Communist Party (CCP) in Beijing, the residential neighbourhoods are controlled by residents wearing red armbands. During traditional Chinese festivals such as the Spring Festival, the city of Shanghai recruits resident volunteers to patrol and denounce the use of fireworks, a practice forbidden in the city centre since 2016. Since the 1950s, residents have been involved in the maintenance of local public order. But how has this commitment been reconfigured within the framework of the neighbourhood, a space subject to specific standards of use (Kaufmann 1983)?

In the scientific field, the theoretical framework focuses on a dialectic between Party-state and volunteers (Zhu 2010; Luova 2011; Shue 2011), in which social control (Wong and Poon 2005, Read 2012) under the Chinese regime is being reconfigured, or even reinforced in more insidious ways, in line with Foucault's concept of governmentality (Chong 2011). This conceptual framework poses a problem of scale and tends to reinforce the intentionality of the state's action on society. It must be remembered that although specific to the Chinese regime, the system under study remains a form of social control at the neighbourhood level - a phenomenon not limited to authoritarian regimes - that has been the subject of studies from the very beginnings of urban sociology. (12) In American cities, for example, Jane Jacobs noticed the "eyes on the street" of social control (Jacobs 1961, p. 35). In the case of China, the inhabitants have been, and are still, active in surveillance systems, originally with a view to the ideological control of morals, and nowadays as vigilantes ensuring the safety of public spaces. But this system also produces other social effects: volunteers make themselves available to help others; and the red-armband patrollers take the opportunity to chat and participate in leisure activities with their neighbours. An ethnographic study on these practices has allowed me to understand the context of the system, half-way between institutional mobilisation and vehicle of socialisation. Somewhere between imposition and moral responsibility, these inhabitants are reshaping the "activism" of the Communist era into a new form of participation.

7. See for example, "Beijing shi min jubao waiji nanzi she kong huo jiangjin 3000 yuan" (The municipality of Beijing has given a 3,000-yuan reward to a man who helped to arrest a foreigner suspected of terrorism), Jinghua shibao (Beijing Times), 1 March 2016.

8. Internal publications of the Ministry of Civil Affairs.

9. "Mei yi tiao hutong dou you women de anbaoyuan" (Our security guards can be found in each hutong), Nanfang Zhoumo (Southern Weekly), 7 August 2008.

10. The use of Lei Feng's image has been modified from that of a Maoist revolutionary to an ideal of civic citizenship, promoting philanthropic values of altruism and common good (gongyi) (Palmer and Ning 2017; Jeffreys and Su 2016).

11. "Beijing shi zhuce shequ zhiyuanzhe yi da 150 wan ren" (In the city of Beijing, 1.5 million volunteers have been registered), Beijing ribao, 3 December 2014.

12. A reference to the Chicago sociological tradition. 
I carried out ethnographic research on resident-volunteering in Beijing as part of doctoral (2007-2012), then post-doctoral (2015), studies. The study of contrasting neighbourhoods enabled me to identify not only the transversal characteristics of this practice, but also its local specificities, notably a more systematic presence in the historic neighbourhoods. The first neighbourhood is located in the alleyways (hutong) of the historic centre of Beijing, in the district of Xicheng, where housing takes the form of single-storey (pingfang) houses built around square courtyards (siheyuan), and where forms of gentrification and tourism are appearing. The second neighbourhood is located in an industrial zone undergoing conversion. Dating from the years 1950 to 1990, this estate of functional, standardised dwellings was attached to work units (danwei), which meant that residents knew each other very well since they were at one and the same time colleagues and neighbours. The third type of neighbourhood is a commodity housing estate (shangpinfang xiaoqu), built in the 2000s after the housing policy reforms and located close to the sixth ring-road in Tongzhou District.

This article analyses volunteering by residents, not only as a political system but also as an activity that is given meaning in context by the players. How do the role-plays and reciprocity that result from residentvolunteering contribute to mixing the sphere of responsibility and the sphere of ordinary sociability? Although volunteers become involved on orders from outside, the practice is also the result of other motives, ${ }^{(13)}$ linking it to the idea of "public altruism" developed by David Palmer and Rundong Ning (Forthcoming). I will first show that volunteering by residents contributes to the control of neighbourhood space, then go on to study the motives for volunteer involvement, demonstrating that forced participation also allows residents to become committed to this local activity.

\section{Resident volunteering, a system for the control of residential space in Beijing}

In the neighbourhoods of Beijing, resident-volunteering constitutes a system that is integrated into local time and space. The system is political in nature, since it is institutionalised and organised by CCP cells, the residents' committees, in the shequ, that is to say, the areas where residential neighbourhoods are managed.

\section{Organisation of the neighbourhood-volunteer networks}

In Beijing, there exists a network for the management of residential areas centred on grassroots organisations that are theoretically "autonomous" (zizhi), such as residents' committees. The latter mobilise "residents' teams" (jumin xiaozu) at the local level. The residents' committee agents base their work on networks of resident-volunteers, managed and accounted for in the official statistics of the neighbourhood communities (shequ). This volunteering policy is part of the "local democracy" component assessed by the street office (jiedao banshichu), the hierarchical superior of the residents' committee. There are three types of permanent volunteer.

Firstly, there are the residents' representatives (jumin daibiao), theoretically elected by the residents, who are responsible for neighbourhood affairs. They serve as go-betweens for the residents and their residents' committee and are invited to voice their opinions during regular meetings.
A representative: "The residents' representatives are a category of volunteers. They are usually elected." The employee of the residents' committee: "But they were not elected here."The man clarifies: "Yes, but according to the rules, there must be an election."She replies: "In general, the election rule is not really applied." (14)

We meet the residents and take note of their remarks. Then we pass on the complaints to the residents' committee. ${ }^{(15)}$

The employees of the residents' committees organise bi-annual assemblies of the residents' representatives (jumin daibiao dahui) to "take stock" (zongjie) of actions that have been carried out and problems that remain to be dealt with. These representatives are also the principal electors in the elections to the residents' committees every three years. ${ }^{(16)}$

The second type of permanent volunteer is the building supervisor (loumen zhang), whose job it is to report his neighbours' problems to the residents' committee. These volunteers are recruited from amongst permanent residents who do not work (retired people, housewives, the unemployed). Their distribution depends on the architecture of the housing, as can be seen from the following table:

\begin{tabular}{|c|c|c|c|}
\hline Neighbourhoods & $\begin{array}{l}\text { Historic } \\
\text { Quarter } \\
\text { (hutong) }\end{array}$ & $\begin{array}{l}\text { Danwei } \\
\text { quarter }\end{array}$ & $\begin{array}{c}\text { Commodity } \\
\text { housing estate } \\
\text { (shangpinfang } \\
\text { xiaoqu) }\end{array}$ \\
\hline \multirow{3}{*}{ 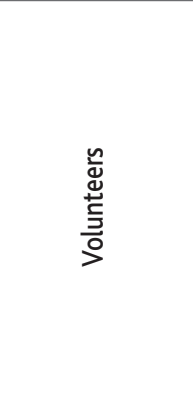 } & $\varnothing$ & $\begin{array}{l}\text { Building } \\
\text { supervisor } \\
\text { (louzhang) }\end{array}$ & $\begin{array}{l}\text { Building } \\
\text { supervisor } \\
\text { (louzhang) }\end{array}$ \\
\hline & $\begin{array}{l}\text { Courtyard } \\
\text { supervisor } \\
\text { (yuanzhang) }\end{array}$ & $\begin{array}{l}\text { Supervisor for the } \\
\text { entrance to the } \\
\text { building } \\
\text { (menzhang) }\end{array}$ & $\varnothing$ \\
\hline & $\varnothing$ & $\begin{array}{l}\text { Landing } \\
\text { supervisor } \\
\text { (cengzhang) }\end{array}$ & $\begin{array}{l}\text { Landing } \\
\text { supervisor } \\
\text { (cengzhang) }\end{array}$ \\
\hline
\end{tabular}

Housing volunteers paste up any new official notices (sent out by the residents' committee) in the communal areas of their building, collect the sanitation charges in the historic and danwei neighbourhoods, ensure good behaviour in the neighbourhood, and serve as intermediaries in case of problems in the building:

Most of the building supervisors are retired and know their apartment block and neighbours very well. The person responsible for the block (louzhang) ensures that life in the building runs smoothly. Today, there are fewer quarrels between neighbours but there are always things that need to be sorted out. For example, if someone dies in one of the flats... ${ }^{(17)}$

We take care of people's problems. If we can't manage, we go see the residents' committee or the level above that, the street office

\footnotetext{
13. The problem of involvement occurs in other contexts (Mazeaud and Talpin 2010).

14. Residents' representative, new neighbourhood, 23 June 2008.

15. Residents' representative, historic neighbourhood, 25 April 2009.

16. According to several field surveys on local elections in 2009, 2012, and 2015

17. Director of the residents' committee, workers' quarter, 28 April 2007.
} 


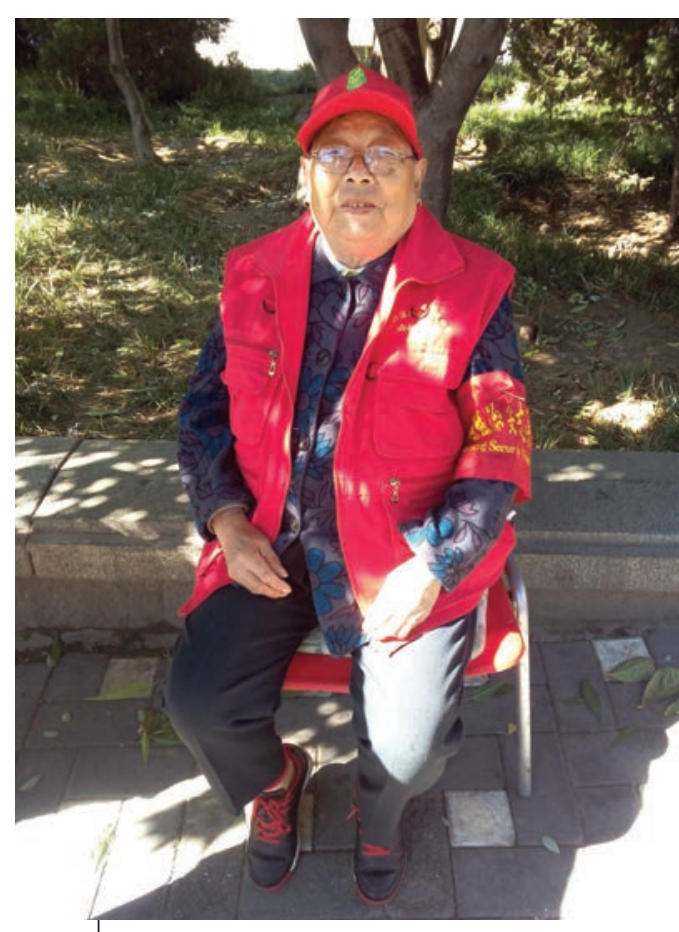

Photo 2 - Volunteer in the historic quarter. ๑) Judith Audin, April 2015

(jiedao banshichu). In general, we can manage small problems. If it's a material problem, we call the management company. The people responsible for the building act as intermediaries for the residents. (18)

In China, the population is huge. [...] So we have to have all these administrative levels. [...] The street office represents the higher level of government, then the residents' committee organises teams of residents like me. [...] It's a sort of chain system that links to the building. If we are looking for someone, we find them very quickly.

The role of the housing volunteers is similar to that of a caretaker. Involved in the management of their block, they obtain this position without really being elected:

The neighbours can contact me during the day with any problems by knocking on my door or telephoning. People who work and who are not in during the day have less contact with the volunteers and their residents' committee. But everyone in the building knows who I am, all the same. ${ }^{(20)}$

Three building supervisors (louzhang) are appointed in the premises of the residents' committee. The residents are then asked if they accept this choice. [...] Of course they approve. How could they not approve? People who are unpaid yet devote themselves to providing them with services, who agree to do this in their spare time. It suits everyone. (21)

These volunteers give the impression of an omnipresent power. They contribute to controlling the space by means of localised eyes and ears. They discipline the population by disseminating the new policies and objectives of the state authorities. (22) In actual fact, surveillance is not systematic whilst remaining attentive to problematic behaviour (intra-family conflicts, problems between neighbours, suspicious activity) or practical problems in the building (damage to communal areas, water leaks). For example, during a day of fieldwork carried out in the office of a residents' committee, I saw an employee ask a building supervisor to write down the names of the residents in his building who were not natives of Beijing (waidiren). She knew their names and apartment numbers by heart. (23) During the SARS epidemic in 2003, these volunteers were also widely deployed in the prevention of disease and to monitor contamination.

The third type of permanent volunteer has the job of supervising public spaces. These are the members of the "security patrols" (zhi'an xunluodui), who wear red armbands (Photo 2).

Besides these, there is a more occasional type of volunteer recruitment, intended for socio-cultural events, and present in all three categories of neighbourhood. As organisers of sport and cultural activities (dance, choral singing, taiji), the agents of residents' committees recruit "talented" residents to give lessons or provide services (street hairdressing). The cultural and sporting activities of each neighbourhood community are presented at regular public performances (at least once every three months). ${ }^{(24)}$ The search for talent aims to give a good image of the neighbourhood, since artistic performances are reported in the "neighbourhood community" (shequ) column of the local paper. ${ }^{(25)}$

\footnotetext{
18. Housing volunteer, workers' quarter, 26 April 2007.

19. Four volunteers, workers' quarter, 1 October 2007.

20. Building supervisor, workers' quarter, 26 April 2007.

21. Apartment block supervisor, workers' quarter, 26 April 2007.

22. Reminiscent of the cells of the DCR in Ben Ali's Tunisia (Hibou 2006, pp. 114-115).

23. Residents' committee, workers' quarter, 10 April 2007.
}

24. For example, during one such show, an 86 year-old resident performed a scene from a Beijing opera (observation, workers' quarter, 28 April 2007).

25. The opera-lover was interviewed by a journalist from the Evening Legal News (Fazhi Wanbao). 
The officials from the residents' committees also mobilise their permanent volunteers to improve the appearance of certain neighbourhoods, notably the historic quarters, whose architecture opens onto public space and for which the town council provides only a limited maintenance service (rubbish collection). For example, on 1 May each year, the building supervisors clean the neighbourhood and take down the advertising posters in the staircases. (26) In this neighbourhood with poorly maintained communal areas, a garden-lover was noticed because his passion fitted into the framework of local "greening":

My hobby has always been gardening. I don't have enough space in my apartment. And it's good for the environment. Last year, I planted jasmine. It smelt lovely. But I don't do it for money. The organisers of the residents' committee noticed I liked planting flowers. They liked that. They asked me what I needed. So I made some suggestions [...]. If I need money to buy seeds or earth, they can give me some. (27)

From time to time, in the lanes of the historic centre, volunteers are recruited during campaigns to promote the "civilised" image of a neighbourhood (wenming) by repainting walls covered with advertisements. (28)

The volunteering system is created and organised by the residents' CCP cell. The object is to demonstrate the participation of local citizens because the officials of the residents' committees are judged by their hierarchical superiors on their ability to mobilise and integrate residents into the official volunteering system. Whilst the aim of occasional volunteering is to project a good image of the neighbourhood by highlighting its "talented personalities," long-term volunteering serves as a means of transmitting information, of mediation, and of mutual assistance in order to ensure order at the local level. Taken together, the contributions of the volunteers (a resident can carry out several types of volunteer work) give the neighbourhood a "civilised" image. Within the three long-term volunteer networks, the "security patrols" with their red armbands knotted around their arms ensure a daily presence outdoors, assisting the police, the chengguan, and the residents' committees.

\section{Micro-politics of the neighbourhood security patrols}

Organised by each residents' committee, the security patrols are tasked with keeping an eye during the day not only on the lanes of the historic centre and the communal areas of secured apartment blocks, but also on public spaces (avenues and squares) near housing, with the aim of complementing the work of the security professionals. The way in which these security teams are organised depends on their locality. Volunteers are chosen according to their address. The patrols are made up of teams of two people, generally of the same sex, ${ }^{(29)}$ and work to a weekly timetable, two hours in the morning and two hours in the afternoon.

Whilst recognising that the "security patrols" are less present in commodity housing estates that are managed by security guards and equipped with video-surveillance systems, the members of these patrols and the agents of the residents' committees emphasise their usefulness:

The security teams are obviously very useful! There are things that the security guards (bao'an) can't see, since they are posted at the entrance of the buildings. The volunteers keep a very close watch on the entrances to the buildings. If there's a problem they can call the police. ${ }^{(30)}$

In a little street near Houhai Lake, several people wearing the red armband are chatting:

"Security in China is above reproach." Not far away, a police officer adds, "It's a really positive system because it gives older people something to do during the day and dissuades delinquents from committing misdemeanours, notably burglaries."

Although there is an imbalance between old and new districts, the presence of volunteers depends on political campaigns, with a presence in the entire town during big events such as the CCP's National Party Congress, which takes place in Beijing, the headquarters of the central state institutions.

Volunteers start when they retire and continue as long as they are able. They must remain attentive, both in summer and winter, and outdoors for the whole day. According to their accounts, it is neither "easy" nor "pleasant," but they are accustomed to it. After their duties have become routine, the officials of the residents' committees no longer systematically take note of the presence of the volunteers and let them organise themselves. If a volunteer cannot attend, he arranges to change shifts with another volunteer. However, if someone makes a habit of being absent, he or she would be upbraided. On 1 May, an employee of the residents' committee returned from an inspection of the neighbourhood in a state of panic: "Not a single security volunteer is at his post!" The secretary of the local Communist Party branch immediately telephoned one of the building supervisors, requesting in urgent, anxious tones that he resolve the problem. ${ }^{(31)}$

The neighbourhood security patrols are characterised, therefore, by the politics of "presence":

The volunteers are present once a week and are not allowed to be absent. Even in winter when it's snowing or raining, we have to be outside in the same spot. ${ }^{(32)}$

They must submit to a long-term schedule. But in fact, the content of the mission is free of any real repressive dimension:

We are not really tasked with security. For example, it's useful if people need to ask the way. We are very familiar with the neighbourhood and can show them which road to take. ${ }^{(33)}$

In the town centre, in general, there are no security problems. So there isn't much to do, in fact. [...] But before, in the 1990s, there was a lot of disorder; there were fights, thefts... ${ }^{(34)}$

26. Observation, workers' quarter, 1 May 2007 and 1 May 2015.

27. Volunteer gardener, 70, workers' quarter, 30 March 2007.

28. Observation and interview with an employee of a residents' committee, historic quarter, April 2015.

29. A narrow majority of women can be observed.

30. Employee of the residents' committee, workers' quarter, 5 April 2007.

31. Observation, residents' committee, workers' quarter, 1 May 2007.

32. Volunteers, historic quarter, 11 April 2007.

33. Two red-armband volunteers, historic quarter, 12 March 2008.

34. Red-armband volunteer, historic quarter, 10 June 2008. 
I have to keep an eye on the road, maintain security. But in actual fact, what I do is above all to set tourists on the right road. (35) There is no insecurity. We ensure there are no thieves, but if we did spot one, we couldn't do anything, just telephone the police by dialling 110. ${ }^{(36)}$

My study noted that on several occasions the security volunteers were even disoriented when a violent incident broke out on their watch (brawls, pickpocketing), not knowing whether to intervene or how. ${ }^{(37)}$ I observed, therefore, a role not so much of repression as of witness to public order, and at the same time a much greater presence in the historic quarters, since the security of commodity housing is the job of other players.

\section{Loyalty, dynamism, and efficiency: "Exemplary" volunteers and retired people ${ }^{(38)}$}

Although short-term volunteers have varied social profiles, long-term volunteers are always long-standing residents of the neighbourhood who are very familiar with its history and geography. The age of the volunteers is an important factor, and the majority are retired. The residents' committee officials choose people with free time, but that is not enough. In particular, residents' representatives and intermediaries in the apartment buildings must be loyal and agree to perform services for the residents' committee. The officials must be able to count on them. The volunteers are requested to identify local problems that the employees of the residents' committee cannot see: material problems in the building, quarrels between neighbours, information about the neighbours. Volunteers are also recruited "because they are able to deal with matters relating to the life of the neighbourhood," (39) that is to say, they are involved in the affairs of the neighbourhood and have a good, long-standing relationship with the other residents. Residents with jobs are absent from the neighbourhood during the day and so have very little contact with the employees of the residents' committee. The latter therefore need people who can act as go-betweens with the absentees. They "choose the volunteers on their personality" (40) to ensure there is dialogue with the other residents. This would suggest a form of recruitment by co-optation. The teams of volunteers are organised by CCP members associated with the local Party cell. "In general, we're all retired." Another person adds, "We are all members of the Communist Party... Well, most of us." (41)

Members of the CCP volunteer easily, but also identify other trustworthy residents. In general, these are residents with a reputation for being zealous workers and who continue to lead a simple life in the neighbourhood, focusing on official community activities. The officials of the residents' committee select these devoted, model residents whose behaviour in public is exemplary. They are politically "conformist":

I am not a volunteer. The residents' committee does not call on me because I opposed the government. For three years, I was under surveillance by the police. [...] I was opposed to the Party. ${ }^{(42)}$

The volunteers are not paid, which maintains the image of spontaneous and self-organised participation by residents in local public affairs:

These are our volunteers. They don't earn money and participate willingly (ziyuan). ${ }^{(43)}$
We give small gifts, but volunteering is not paid. It is symbolic; we are thanking them for their services. ${ }^{(44)}$

Volunteering implies both moral and physical commitment. The residents' committees look for "active" (jiji) retired people, that is to say, motivated and in fairly good health. They fit the description of an "active and likeable pensioner," an "indefatigable person" as defined by Jay Rowell in East Germany (Rowell 2006, p. 285):

An active pensioner is someone who does not want to endure retirement but who wants to continue to learn new things or to teach. We are always looking for this type of person, we need them. ${ }^{(45)}$

We spot them in the cultural and sports leisure activities we organise. We can see these people are energetic, have a sense of responsibility (zerengan), and are able to participate. ${ }^{(46)}$

In particular, the security patrols need to be in good physical condition in order to keep up the pace needed for outdoor patrol duties:

In each apartment block, a volunteer serves as an intermediary. In the street, volunteers wearing red armbands keep watch. If there are intruders, they can spot them. My sight is bad. Before, I too was a member of the security patrols, but I can't see clearly anymore. What good would I be as a volunteer if there were a thief and I couldn't see him? ${ }^{(47)}$

The resident-volunteers are recruited to serve as intermediaries by virtue of being long-standing residents of Beijing, and because of their involvement in their neighbourhoods and official structures of local organisations. Physical and normative surveillance of the neighbourhood by volunteers chosen by the CCP cells of the residents' committees has been presented in this first section as the main vector of resident participation in these state structures that are attempting to gain legitimacy in the context of the transformation of power relationships in favour of the new property owners (Guan and Cai 2015; Wang 2013). But resident-volunteering is also based on moral commitment and the practices of the players in context.

\section{Moral dimensions of the commitment of volunteers in neighbourhood networks}

The volunteering system in the neighbourhoods of Beijing is organised, run, and implemented by a para-administrative chain at the residents' com-

35. Red-armband volunteer, historic quarter, 10 June 2008.

36. Red-armband volunteer, historic quarter, 18 June 2008.

37. Observations, historic quarter, April-May 2015.

38. An idea discussed by Isabelle Thireau, seminar on "Social norms and legitimacy in the People's Republic of China," EHESS, 2014-2015.

39. Female resident, workers' quarter, 25 April 2007.

40. Volunteer housing intermediary, historic quarter, 5 November 2008.

41. Security Volunteers, historic quarter, 18 June 2008.

42. Recipient of the minimum urban income (dibao), workers' quarter, 18 April 2007.

43. Employee of the residents' committee, workers' quarter, 5 April 2007.

44. Director of a residents' committee, historic quarter, 21 May 2008.

45. Deputy director of the residents' committee, new quarter, 18 March 2007

46. Director of a residents' committee, historic quarter, 21 May 2008.

47. Volunteer gardener, workers' quarter, 30 March 2007. 
mittee level. But the participation of the residents in this system reveals fairly deep-seated motives that reveal the way in which individuals appropriate this activity.

\section{A (non)voluntary commitment by residents who appropriate their position}

It's not really volunteering. It's a duty (yiwu). ${ }^{(48)}$

This extract from an interview directly highlights the ambiguities of this commitment. No volunteer came forward spontaneously. They all confirm:

The residents' committee sought us out. (49)

The residents' committee has information on each resident (age, professional situation). They asked us to become volunteers as soon as we retired. It's not compulsory, we can refuse. But in general, we don't have much to do (baitian dou mei shi), so we rarely refuse. ${ }^{(50)}$

The residents' committee seeks us out directly and asks us if we are willing to participate. In general, we have to agree, or they may take it badly. Afterwards, they check that we come each week. ${ }^{(51)}$

The residents were therefore not the initiators of the commitment to volunteering. Some of them even say they do not particularly welcome it.

There is no feeling of attachment. We volunteer. That's all. (52)

It's like a mission (renwu), a duty (yiwu), there's no enthusiasm. Personally, I don't really like volunteering, but my husband doesn't mind so he replaces me. I'm retired, but I find that it's just like a job. ${ }^{(53)}$

The officials of the residents' committees use tactics of persuasion to create personal relationships with certain residents. They target retired people who fear that "free time" is a source of idleness:

I have been a volunteer for around ten years, since my retirement. Before, it wasn't my concern. I was working. ${ }^{(54)}$

Volunteers, and more generally the neighbourhood's elderly residents, have nothing else to do during the day than to meet on a bench after meals and pass the time of day together. [...] Moreover, these are the people who come on the group outings we organise for them. They don't go out on their own initiative. ${ }^{(55)}$

The recruitment strategies are always relatively similar. Officials from the residents' committee come to an individual's home with a view to influencing their response (Joule and Beauvois 2004). They begin by complimenting them, saying they are trustworthy and that it would help a lot if they agreed. They also cite the case of an elderly resident in the same building who has health problems. Many volunteers admit having been approached in this way, under the scrutiny of neighbours:

It was the residents' committee that asked us to become volunteers to replace certain residents who were now too old. They were over
70 and could no longer patrol. So we could not refuse, out of respect for those people. ${ }^{(56)}$

"Young pensioners" therefore become members of the "security patrols" because they do not dare refuse. This form of civic duty is part of the social conventions that have been assimilated by long-standing residents. The feeling of belonging to a neighbourhood as well as the relationships developed with neighbours creates obligations. Being retired and having free time leads to feelings of guilt at not participating:

In the beginning, it was the residents' committee that came to ask me if I would agree to become a volunteer. [...] Two officials came to my house and explained that a neighbour on the ground floor had difficulty walking. As she could no longer perform her duties he was looking for someone in the same building to replace her. [...] All the neighbours know each other, so I would feel too embarrassed (bu hao yisi) to refuse. ${ }^{(57)}$

Anxiety over free time is widespread amongst urban Chinese pensioners and induces in them a strongly marked sense of responsibility (Rochot 2017). The idea of "volunteering" is therefore ambiguous, since the commitment is influenced by the norm governing the use of free time for the common good against idleness, counter-productivity, and selfishness. ${ }^{(58)}$

The recruitment of volunteers by co-optation is mixed in with other motives. The object of the "security patrols" is to provide a guarantee of safety. Chinese towns are seen as dangerous and full of risk. For example, personal possessions in a public (bicycles) or private (home) space are not fully insured against theft and damage. As a result, any additional surveillance such as the presence of red-armband volunteers who are able to call the police and bear witness to what they have seen is welcomed, particularly in the historic quarters and work unit estates, where security is more limited. Risk acts as an effective factor in mobilisation:

Naturally there are security problems in the neighbourhood such as theft and scams. Look at that little street just behind - a man was killed there! (59)

Of course there are security problems... Well, not in our building, but in the one next to us, for example, there have been burglaries. ${ }^{(60)}$

This volunteering is very important; it's a guarantee of security and order. ${ }^{(61)}$

\footnotetext{
48. Four red-armband volunteers, historic quarter, 18 June 2008.

49. Volunteer, workers' quarter 22 September 2007.

50. Red-armband volunteer, historic quarter, 10 June 2008.

51. Red-armband volunteers, historic quarter, 11 April 2007.

52. Five red-armband volunteers, historic quarter, 3 May 2007.

53. Red-armband volunteer, workers' quarter, 3 May 2007.

54. Building supervisor, workers' quarter, 26 April 2007.

55. Two employees of the residents' committee, workers' quarter, 6 June 2008

56. Red-armband volunteer, workers' quarter, 25 April 2007.

57. Red-armband volunteer, workers' quarter, 10 May 2007.

58. Recipients of welfare payments (dibao) had to become volunteers. (Employees of the residents' committee, historic quarter, 3 April 2007).

59. Red-armband volunteer, historic quarter, 6 April 2007.

60. Female resident, workers' quarter, 31 March 2007.

61. Red-armband volunteer, workers' quarter, 5 April 2007.
} 
The red armband is a way of warning off thieves. It's a means of dissuasion. ${ }^{(62)}$

The 17th Congress of the Communist Party is about to take place. This event takes place every four years and it's important to provide security for it, as no problems must occur on those days. [...] No, I am not a member of the Communist Party. But it's important to ensure security; it's the task and duty of every inhabitant. [Have you ever witnessed security problems?] No, never. Why would there be any problem? It's precisely thanks to all the security organisations that we have in China! (63)

This account demonstrates the social importance of fear in residential space (Li 2010), through which the volunteers justify the usefulness of their presence.

Moreover, volunteering is carried out by long-standing residents who have a strong attachment to their local area, know it well, and move around it frequently. It is more firmly anchored in the old quarters, where resident delegates have always existed.

It has existed for a long time, since the Cultural Revolution! We call it "mobilising the masses" (fadong qunzhong). [...] Previously, the residents' committees were made up of housewives who did not receive a salary and who mediated in disputes and ensured order in the neighbourhood. [...] Now they are salaried, so they ask residents to ensure harmony amongst neighbours. ${ }^{(64)}$

This quotation, which refers to the militancy of the Maoist era, shows that it constituted a key moment in the political mobilisation and ideological control of the population in China and that it represents a turning-point in the history of the maintenance of public order. As for the idea of "harmony," this confirms that the official slogans have been assimilated by the volunteers whilst at the same time bearing witness to transformations in the system of local surveillance. In the streets of the historic city centre and in the socialist housing estates, there is a heavy presence of volunteers because this kind of surveillance systems has persisted there for a long time. In a town that has seen rapid change in both social and spatial terms, the continuation of these practices allows older people, animated by a distinct feeling of insecurity, to find familiar landmarks and develop shared social codes. Lastly, the volunteers adapt to the constraints of this activity since they create "ways of doing" that are compatible with their tastes. Volunteering stimulates sociability. Most "security patrols" do other things apart from patrolling: they play cards, converse, make friends, etc. These methods of sociability are characteristic of older, or less mobile (geographically and socially) people, in particular those from modest backgrounds. So volunteering is institutionalised by the residents' committee but is appropriated by the residents, who also use it to create their social space. The motivation of the volunteers is therefore influenced by generational and geographical variations in the way in which free time and security is seen, and by local political and urban cultures.

\section{Three variations on the services: Resident volunteering in neighbourhood governance}

Derived from the famous Maoist slogan "Serve the People" (wei renmin fuwu), the idea of "service" is omnipresent in neighbourhood volunteering, yet is nonetheless ambiguous. The activity reveals several levels of service.

Firstly, volunteering provides services to others and is an activity that aims to serve the public good (gongyi) rather than personal interests. Officially and in practice, volunteers offer services that stem from a sense of civic and moral duty, for the benefit of residents and passers-by in the neighbourhood. Behind the official political slogans, the motives for making this sort of commitment are rooted less in ideology than in the past. Volunteers use the idea of "public good" (gongyi) in a more psychological and social sense that even extends to religious motives. ${ }^{(65)}$ Volunteering is, in fact, motivated by the moral satisfaction of doing good deeds. This is borne out by the frequent references by volunteers to Lei Feng, a historic example of giving of oneself to accomplish "good deeds," but in an individualised manner, as David Palmer and Rundong Ning (2017, p. 37) have observed. The idea of services offered to others, admittedly in a limited capacity, reinforces the norms of civic duty and moral responsibility, since volunteers appear to be trustworthy people:

You ask what the red armband is for? It guarantees that I am someone with good intentions and that you can ask me for help. There are so many con artists around nowadays that people need to be reassured that I am someone they can trust. ${ }^{(66)}$

Moreover, residents with a job, who are absent from the neighbourhood during the day and are not much concerned by the activities of the residents' committees and the volunteers, also believe that the latter can but be useful and do not wish to see them disappear. A second level of service exists centred on the mutual exchange of favours between volunteers and the officials of the residents' committee:

Before, I wanted to transform my rural hukou into an urban hukou. I was born in Beijing but was sent into the countryside during the Cultural Revolution, hence the rural hukou. So I appealed to the residents' committee. They asked me to become a security volunteer. I agreed. When I obtained my urban hukou I didn't dare stop. (67)

Services form a chain in the form of favour and counter-favour as part of a network based on reciprocity (Yan 1996; Yang 1994). On a professional level, the vast majority of volunteers come from the public sector. These people are more willing to join official social organisations. In addition, they see retirement as a "free salary" that must be paid for. Becoming a volunteer is, for many, a means of "giving back to the state."

We receive money from the state although we don't work. So our good deeds are a way of giving something back to the state. ${ }^{(68)}$

I am 77 and I began volunteering when I was 50. I was a manual worker and was given early retirement when the factory closed. I volunteer to serve the people (wei renmin fuwu) because in giving up

62. Red-armband volunteer, workers' quarter, 10 May 2007.

63. Red-armband volunteer, historic quarter, 11 October 2007.

64. Red-armband volunteer, historic quarter, 6 May 2015.

65. For example, near the Guanghua temple, one volunteer is younger than the others. His motive is religious: he is Buddhist (Red-armband volunteer, historic quarter, 6 April 2007).

66. Security volunteer, historic quarter, 30 September 2015.

67. Security volunteer, historic quarter, 18 April 2007.

68. Two red-armband volunteers, historic quarter, 7 May 2015. 
my free time, I can give something to the state by contributing to the public good (gongyi). ${ }^{(69)}$

In this circle of reciprocity, the co-optation of resident-volunteers by the residents' committees is a component in the mechanism of public action, directing it into the realm of security (mutual surveillance) and practical action (mutual favours). The volunteers appreciate the little gifts they receive, distinctive rewards (coats bearing the name of the neighbourhood), or symbolic monetary payments distributed during the traditional festivals.

We have just finished a meeting with our volunteers. To thank them, we promised we would soon organise a series of lectures on health, inviting doctors to give free consultations. The pensioners were very pleased. ${ }^{(70)}$

The status of volunteer does not necessarily mean submission to the local authorities, however. Under cover of their public role, volunteers can exchange other sorts of information. To all appearances, a certain resident member of the "security patrols" would seem to be a dedicated neighbourhood militant. The residents' committee officials do not know that this woman and three other volunteers spend a great deal of their patrolling time complaining of the injustices they feel have been done to them and insulting the residents' committee. Neither do they know that she spends her other days protesting in the Beijing office of Letters and Visits over a housing ownership problem. ${ }^{(71)}$

Nonetheless, because they involve reciprocity, certain residents refuse to become involved in these relationships of dependence on the CCP system and do not become volunteers. ${ }^{\text {(72) }}$

Finally, a third level of service can be identified: mutual services between the volunteers. Volunteering has proved compatible with the lifestyle of many older people who need to remain active and spend time outdoors to "take some exercise" (duanlian shenti). This "physical participation" is linked to motives of health and leisure. Elderly volunteers say that the activity stimulates their mind more effectively than remaining at home and helps them avoid early-onset dementia. Today's volunteering has redefined the activism of early Maoist China in favour of a moral and social commitment on the part of older people. I tell the volunteers that in France this type of volunteering does not exist. A woman reacts to this, saying:

But who is in charge of controlling the population, then? And don't older people with nothing to do volunteer? What on earth do they do, then? (73)

In Beijing, volunteering enables older people to continue to feel useful and gives them a sense of satisfaction that explains their long-term commitment, yet without demanding too much of them or placing them under undue stress. The rhythm of this type of regular activity is useful in the lifestyles of pensioners faced with time to spare and on whom solitude weighs heavily.

We've been volunteers for ten years. [...] We like to do it because we're retired and have nothing to do during the day. [...] And it's a way of taking exercise. ${ }^{(74)}$

Volunteering is a vector of socialisation and minor prestige. Many volunteers are happy to be using their local knowledge for the good of the com- munity. In particular, the red armband of the "security patrols," a strong symbolic element, gives the volunteers a form of moral exemplarity.

The many motives of the volunteers contribute to the exercise of public action. As a network of exchange of local knowledge and also of know-how, the system is one example of public action practiced "under" the state. This type of volunteering allows residents' committees to benefit not only from local assistance and shared information but also from advice and criticism concerning the neighbourhood. Certain volunteers put forward suggestions, since the various needs and demands can be taken into account. Their more intimate knowledge of places and people enable certain problems to be solved. "There is a feeling of responsibility towards people...especially people who do not come from around here and who cause problems." (75)

Local management, since it makes use of resident-volunteers, constitutes a logistical facility in the maintenance of public order. If these volunteers can prove devoted in helping passers-by who have lost their way or in helping people in difficulty by directing them or passing on their messages, they can also prove particularly active in denouncing deviant behaviour such as begging, street vending, and gossiping, which, although it functions as entertainment, also contributes to forms of stigmatisation even exclusion (Elias 1985).

\section{Conclusion}

This ethnographic study on "volunteer" (zhiyuanzhe) residents in the neighbourhoods of Beijing highlights all the ambiguities inherent in grassroots Chinese organisations. By engaging in volunteering, residents respond to an official demand defined by the local authorities, in what appears to be a form of "institutional militancy" (Politix 2005). The call to civic duty is presented as spontaneous and active participation on the part of the volunteers. The promotion of volunteering allows the residents' committees to maintain an image of "local democracy" (jiceng minzhu): to the extent that the volunteers agree to "play the good citizen" (Talpin 2006), the system includes forms of participation in local affairs. However, it remains the case that participants are selected and controlled by CCP cells at the level of the residents' committees, against a background of indifference on the part of other residents towards these players. For their part, the volunteers accept these demands because they are motivated by a sense of moral responsibility, and their mission is a source of sociability.

The study of resident mobilisation also revealed the motives for this type of commitment as well as specific local usage, in that not all volunteers become involved to the same degree in their neighbourhood, and that differences exist depending on the type of housing. The question therefore arises of closed architecture and the predominance of management norms in the commodity housing units in Chinese towns, with their increasingly sophisticated security equipment that has resulted in the computerised monitoring of public space, and with it the question of whether residents' participation in local affairs might take a new direction in the context of the development of property rights and the role of owners' committees toblis the detriment of the figure of the resident (Rocca 2017; Guo Shen and Chen 2014; Merle 2014).

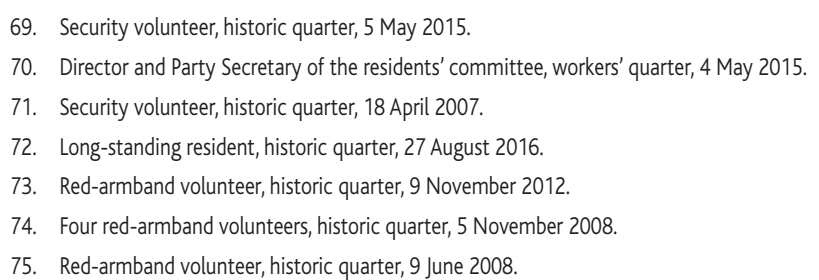


I Translated by Elizabeth Guill

I Judith Audin is a postdoctoral fellow at Sciences Po Aix (CHERPA), an associate PhD at EHESS (CECMC) and incoming chief editor of China Perspectives.

Article received on 27 May 2016. Accepted on 21 March 2017.

\section{References}

BRAY, David. 2005. Social Space and Governance in Urban China: the Danwei System from Origins to Reform. Stanford: Stanford University Press.

CARON, Emmanuel. 2013. "Interactions Between Chengguan and Street Vendors in Beijing: How the Unpopularity of an Administration Affects Relations with the Public." China Perspectives 2013(1): 17-28.

CHONG, Gladys Pak Lei. 2011. "Volunteers as the 'New' Model Citizens: Governing Citizens Through Soft Power." China Information 25(1): 33-59.

COLOMER, Josep M. 2000. "Watching Neighbors: The Cuban Model of Social Control." Cuban Studies 31: 118-138.

DOYON, Jérôme. 2016. Rejuvenating Communism: The Communist Youth League as a Political Promotion Channel in Post-Mao China. Paris: Political Sciences Thesis, Sciences Po.

ELIAS, Norbert. 1985. "Remarques sur le commérage" (Observations on gossip). Actes de la recherche en sciences sociales 60(1): 23-29.

GIRALDOU, Marion. 2016. "La mue des comités de défense de la révolution" (The transformation of the committees for the defence of the revolution). Le Monde Diplomatique 743.

GUAN, Bing, and Yongshun CAI. 2015. "Interests and Political Participation in Urban China:The Case of Residents' Committee Elections." China Review 15(1): 95-116.

GUO, Yuhua, SHEN Yuan, and CHEN Peng (eds.). 2014. Juzhu de zhengzhi : dangdai dushi de yezhu weiquan he shequ jianshe (The politics of housing: mobilisations for the rights of new homeowners and the construction of neighbourhood communities in contemporary metropolises). Guilin: Guangxi shifan daxue chubanshe.

HIBOU, Béatrice. 2006. La force de l'obéissance : économie politique de la répression en Tunisie (The strength of obedience: political economy of the repression in Tunisia). Paris: La Découverte.

JACOBS, Jane. 1961. The Death and Life of Great American Cities. New York: Random House.

JEFFREYS, Elaine, and Xuezhong SU. 2016. "Governing through Lei Feng: a MaoEra Role Model in Reform-Era China." in David Bray and Elaine Jeffreys (eds.), New Mentalities of Government in China, Londres: Routledge. 30-55.

JOULE, Robert-Vincent and Jean-Léon BEAUVOIS. 2004. Petit traité de manipulation à l'égard des honnêtes gens (Brief treaty on manipulation for use by honest people). Grenoble: Presses universitaires de Grenoble.

KAUFMANN, Jean-Claude. 1983. La vie hlm: usages et conflits (Life in social housing: customs and conflicts) Paris: Editions ouvrières.

LI, Zhang. 2010. In Search of Paradise. Middle-Class Living in a Chinese Metropolis. Ithaca: Cornell University Press.

LUOVA, Outi. 2011. "Community Volunteers' Associations in Contemporary Tianjin: Multipurpose Partners of the Party-state." Journal of Contemporary China 20(72): 773-794.

MAZEAUD, Alice, and Julien TALPIN. 2010. "Participer pour quoi faire ? Esquisse d'une sociologie de l'engagement dans les budgets participatifs" (Why should we participate? Outline of a sociology of involvement in participatory budgets). Sociologie 1(3): 357-374.

MERLE, Aurore. 2014. "Homeowners of Beijing, Unite! The construction of a collective mobilisation." China Perspectives 2014(2): 7-15.
MOK, Bong-ho. 1988. "Grassroots Organizing in China: The Residents' Committee as a Linking Mechanism Between the Bureaucracy and the Community." Community Development Journal 23(3): 164-169.

PALMER, David, and Rundong NING. 2017. "The Resurrection of Lei Feng: Rebuilding the Chinese Party-State's Infrastructure of Volunteer Mobilization." International Conference on "Mobilized Contention", University of Hong Kong, January 12-13.

PALMER, David, and Rundong NING. Forthcoming. Public Altruism in China: Volunteering, Individualization and Civil Society.

Politix (Editorial Board). 2005. "Militantismes institutionnels" (Forms of institutional militancy). Politix 70.

READ, Benjamin L. 2012. Roots of the State: Neighborhood Organizations and Social Networks in Beijing and Taipei. Stanford: Stanford University Press.

ROCCA, Jean-Louis. 2017. The Making of the Chinese Middle Class: Small Comfort and Great Expectations. Basingstoke: Palgrave MacMillan.

ROCHOT, Justine. 2017. "'Le corps est le capital de la Révolution': Pratiques de soins et gestion du corps vieillissant dans les espaces de sociabilité de retraités de Chine urbaine contemporaine" (The body is the capital of the revolution": Care practices and management of the ageing body in the social spaces of pensioners in contemporary urban China). Paper presented in a seminar on contemporary China, CERI, Sciences Po, 26 January 2017.

ROWELL, Jay. 2006. Le totalitarisme au concret: les politiques du logement en RDA (Totalitarianism in practice: housing policies in GDR). Paris: Economica.

SHAW, Victor N. 1996. Social Control in China: A Study of Chinese Work Units. Westport: Praeger.

SHUE, Vivienne. 2011. "The Political Economy of Compassion: China's 'Charity Supermarket' Saga." Journal of Contemporary China 20(72): 751-72.

SOLOMON, Richard H. 1969. "On Activism and Activists: Maoist Conceptions of Motivation and Political Role Linking State to Society." The China Quarterly 39: 76-114.

TALPIN, Julien. 2006. "Jouer les bons citoyens : Les effets contrastés de l'engagement au sein de dispositifs participatifs" (Playing the good citizen:The contrasted effects of engagement inside deliberative arenas). Politix 75: 11-31.

WALDER, Andrew G. 1986. Communist Neo-Traditionalism: Work and Authority in Chinese Industry. Berkeley: University of California Press.

WANG, Di. 2013. "Operating Norms and Practices of Residents' Committees: The Consequences and Limits of Management by Numbers." China Perspectives 2013(1): 7-16.

WHYTE, Martin K., and William L. PARISH. 1984. Urban Life in Contemporary China. Chicago: Chicago University Press.

WONG, Linda, and Bernard POON. 2005. "From Serving Neighbors to Recontrolling Urban Society: The Transformation of China's Community Policy." China Information 19(3): 413-442.

YAN, Yunxiang. 1996. The Flow of Gifts: Reciprocity and Social Networks in a Chinese Village. Stanford: Stanford University Press.

YANG, Mayfair. 1994. Gifts, Favors, and Banquets: The Art of Social Relationships in China. Itaca: Cornell University Press.

ZHU, Jiangang. 2010. Guo yu jia zhijian: Shanghai linli de shimin tuanti yu shequ yundong de minzu zhi (Between family and the state: an ethnography of the forms of civil associations and community movements in a Shanghai lilong). Beijing: Shehui kexue wenxian chubanshe. 